\title{
The Effectiveness of Buzz Group Disscussion on Knowledge and Attitudes about Prannal Sex in Adolescents at Vocational School of Pencawan Medan
}

\author{
Serly Monika Br Sembiring \\ Midwifery Undergraduate Study Program INKES SUMUT, Indonesia \\ Corresponding author email: serlykembaren25@gmail.com
}

\begin{abstract}
The results of the report from the Demographic and Health Survey, especially the Adolescent Reproductive Health (KRR) component (2012) were found in adolescents aged 15-19 years, the largest proportion of first dating times at the age of 15-17 years. About 33.3\% of girls and 34.5\% of boys aged 15-19 years started dating when they were not yet 15 years old. Various other factors cause students to engage in premarital sex, such as communication with family, lack of information about the impact of premarital sex. This research is analytic with approach design cross-sectional. The population in this study were adolescents with a sample of 50 respondents, the sampling technique was purposive sampling. Collecting data using a questionnaire which will be processed with the test chi-square, with $p=0.05$. Adolescent knowledge showed that the value of $p=0.001$ ( $p<0.05)$, meaning that there was a significant difference between the knowledge before and after being given health education about free sex. Attitudes, the value of $p=0.001(p<0.05)$ was obtained, meaning that there was a significant difference between the knowledge before and after being given health education about free sex.

Keywords---attitudes, buzz group discussion, knowledge, premarital sex.
\end{abstract}

\section{Introduction}

The results of the report from the Demographic and Health Survey, especially the Adolescent Reproductive Health (KRR) component (2012) were found in adolescents aged 15-19 years, the largest proportion of first-time dating ages 15-17 years. About 33.3\% of girls and 34.5\% of boys aged 15-19 years started dating when they were not yet 15 years old. According to Sarwono (2011), adolescents are prone to premarital sexual behavior which has an impact on pregnancy outside of marriage, the impact of pregnancy outside of marriage, namely abortion, the risk of childbirth, divorce from young couples, sexual relations at a young age that are at risk of mental disorders such as stress, because stress is a person's emotional reaction to a new environment (Suhron et al., 2018; Yusuf Ah et al., 2019; Suhron M et al., 2020)

The results of the IDHS (2012) KRR show that adolescent knowledge about health Inadequate reproduction can be seen with only $35.3 \%$ of female adolescents and 31.2\% of male adolescents aged 15-19 years who know that women can get pregnant with one sexual intercourse. Likewise, the symptoms of PMS are less well known by teenagers. Information about HIV was relatively more widely accepted by adolescents, although only $9.9 \%$ of girls and $10.6 \%$ of boys had comprehensive knowledge about HIV-AIDS. The place for youth ministry is also not widely known by teenagers. Based on Sekarrini (2012) research, 39.3\% of students of SMK health in Bogor Regency area sexual behavior in mild categories such as chatting, watching movies together, walking together, holding hands, and hugging, while $60.7 \%$ of sexual behavior is at serious risk such as kissing lips, kissing the neck, feeling the sensitive area, touching genitals and having sex. Various other factors cause students to engage in premarital sex, such as communication with family, lack of information about the impact of premarital sex. For this reason, it needs maximum effort and support from all parties, especially schools because students' general knowledge tends to be obtained in schools other than in their families, such as family stress in dealing with individual and community psychological pressures that cause self-esteem to experience disruption (Suhron, 2017; 2016; Yusuf et al., 2020; 
Rahmad et al., 2020). One of the ways to provide information to students can be done by using group guidance. Based on Diana Oktaviani (2015) research, there was a decrease in sexual behavior in the discussion technique group guidance service. The Wilcoxon test results showed that there was an influence on sexual behavior before and after attending the discussion technique group guidance service (Ansari-Lari et al., 2010; Eriksen \& Fallan, 1996).

Research conducted by Puput, there is a significant difference between the lecture method and the method of group discussion on the level of knowledge of students at JUNIOR HIGH SCHOOL Negeri 19 Purworejo. The group discussion method is more effective than the lecture method. It is in line with the fact that the provision of information about the impact of premarital sex is still rarely accepted by students and schools tend to be more curative than preventive in handling cases of premarital sex. It is very worrying if this continues because students are the nation's next-generation who play an important role in the progress of the country in the future. Seeing the current phenomenon, students need to be fortified with knowledge and understanding of the impact of premarital sex.

Based on the survey results by conducting interviews with counseling teachers, the researcher obtained information that there had never been a small group discussion about premarital sex among adolescents. According to the counseling teacher, students do not feel ashamed and uncomfortable when making out and hitting the teacher. Based on this background, research will be carried out on "the effect of small group discussions on knowledge and attitudes of adolescents about premarital sex at SMK Pencawan Medan".

\section{Method}

The design of this research is analytic with the Quasy Experiment which is carried out on a set of objects which usually aims to see a description of the phenomena that occur in a certain population (Notoatmodjo, 2010). Location and Time of Research the research was conducted at SMK Pencawan Medan with the consideration that it had never been used as a sample in the study. Population and Sample Population is the whole object under study (Notoatmodjo, 2007). The population in this study were all adolescents of class XII at SMK Pencawan Medan as many as 100 people. Samples were obtained by 50 people. Data Collection Method Data in this study were obtained using primary data obtained using a questionnaire sheet by distributing questionnaires to respondents and secondary data.

\section{Results}

Table 1

Knowledge for Class X Children Before and After Small Group Discussions on Premarital Sex at Pencawan Private Vocational High School in 2018

\begin{tabular}{ccccc}
\hline & \multicolumn{2}{c}{ Good } & \multicolumn{3}{c}{ Not Good } \\
\cline { 2 - 5 } Knowledge & F & $\%$ & F & $\%$ \\
\hline Pre Test & 32 & 64 & 18 & 36 \\
\hline Post Test & 42 & 84 & 8 & 16 \\
\hline
\end{tabular}

The results of the study can be seen that knowledge of class XII children at SMK Swasta Pencawan Medan before the small group discussion was held as many as 32 respondents (64\%) had good knowledge, and as many as 18 respondents (36\%) had poor knowledge. After a small group discussion, the knowledge of class XII students of SMK Swasta Pencawan Medan increased to 42 respondents (84\%) who had good knowledge, as many as 8 people (16\%) had a bad knowledge. 
Table 2

Frequency Distribution of Attitudes Before(Pre) and After (Post) Small Group Discussions are Conducted with Adolescents at the Private Vocational School of Pencawan Medan in 2018

\begin{tabular}{ccccc}
\hline & \multicolumn{2}{c}{ Positive } & \multicolumn{3}{c}{ Negative } \\
\cline { 2 - 5 } Attitudes & F & $\%$ & F & $\%$ \\
\hline Pre Test & 32 & 64 & 18 & 36 \\
\hline Post Test & 43 & 86 & 7 & 14 \\
\hline
\end{tabular}

The results showed that the attitudes of class XII children at SMK Swasta Pencawan Medan before the small group discussion were held as many as 32 respondents (64\%) had positive attitudes, and as many as 18 respondents (36\%) had negative attitudes. After a small group discussion, Siakp class XII SMK Swasta Pencawan Medan increased to 43 respondents $(86 \%)$ having positive attitudes, as many as 7 people (14\%) having negative attitudes.

Table 3

The Influence of Knowledge before and After Small Group Discussions on Premarital Sex on Adolescents in Pencawan Medan Private Vocational School

\begin{tabular}{llccc}
\hline \multicolumn{1}{c}{ Variable } & Mean & $\begin{array}{c}\text { Mean } \\
\text { Difference }\end{array}$ & $\begin{array}{c}\text { Standard } \\
\text { Deviation }\end{array}$ & p-value \\
\hline Pre-test & 1.64 & & 0.156 & 0.485 \\
\cline { 1 - 1 } Post-test & 1.84 & 0.370 & \multirow{2}{*}{0.001} \\
\hline
\end{tabular}

The results showed that there were differences in knowledge before and after small group discussions about premarital sex. The results showed that the mean knowledge of class $\mathrm{X}$ children before conducting small group discussions about premarital sex was 1.64 with a standard deviation of 0.485 , while the average knowledge of adolescents after doing premarital sex was 1.84 with a standard deviation of 0.370 . The knowledge before and after the small group discussion was 0.156 . The statistical paired t-test test was used to determine the difference in knowledge of the pre-post-test. From the research results obtained p-value $=0.001(\mathrm{p}<0.05)$, meaning that there is a significant difference between the knowledge before and after being given health education about free sex.

Table 4

The Influence of Attitudes before and After Small Group Discussions on Premarital Sex on Adolescents in Pencawan Medan Private Vocational School.

\begin{tabular}{lcccc}
\hline \multicolumn{1}{c}{ Variable } & Mean & $\begin{array}{c}\text { Mean } \\
\text { Difference }\end{array}$ & $\begin{array}{c}\text { Standard } \\
\text { Deviation }\end{array}$ & p-value \\
\hline Pre-test & 1.64 & 0.156 & 0.485 & 0.001 \\
\hline Post-test & 1.86 & & 0.351 & 0.001 \\
\hline
\end{tabular}

The results showed that there were differences in attitudes before and after small group discussions about premarital sex. The results showed that the average knowledge of class $\mathrm{X}$ children before conducting small group discussions about premarital sex was 1.64 with a standard deviation of 0.485 , while the average knowledge of adolescents after doing premarital sex was 1.86 with a standard deviation of 0.351 . The significance of knowledge before and after a small group discussion was 0.156 . The statistical paired t-test test was used to determine the differences in the attitude of the pre-post-test. From the research results obtained $\mathrm{p}$-value $=0.001(\mathrm{p}<0.05)$, meaning that there is a significant difference between the knowledge before and after being given health education about free sex. 


\section{Discussion}

From the research results obtained $\mathrm{p}$-value $=0.001(\mathrm{p}<0.05)$, meaning that there is a significant difference between the knowledge before and after a small group discussion about premarital sex among adolescents at SMK Sawasta Pencawan Medan. This is in line with the research of Salman (2012), with the title differences in behavior before and after being given health education to adolescents about free sex at junior high school Negeri 3 Takengon, Central Aceh Regency, where the behavior of adolescents after being given health education at adolescents about free sex is with good knowledge, positive adolescent attitudes, and good adolescent actions (Ghanizadeh et al., 2006; Mentari et al., 2019).

According to Sarwono (2013), several factors cause sexual behavior in adolescents, including hormonal changes that increase sexual desire (sexual libido) in adolescents, delaying the age of marriage, taboos/prohibitions in society for sexual behavior before marriage, lack of information. Teenagers get about sexuality and related things in it and the more free relationships. According to Tana (2010) various possible factors that can affect health education are material providers, extension media, and targets to be given intervention. In line with the theory of knowledge according to Notoatmodjo (2011), that formal education and information affect a person's level of knowledge. Efforts to make people behave or adopt health behaviors using persuasion, persuasion, appeal, solicitation, providing information, providing awareness, and so on. It can be concluded that health education is a form of intervention or effort aimed at behavior, so that community behavior is conducive to health (Shi et al., 2020; Yabanc1 et al., 2014).

\section{Conclusion}

There is a significant difference between the knowledge before and after being given health education about free sex. There are differences in attitudes before and after small group discussions about premarital sex.

\section{References}

Ansari-Lari, M., Soodbakhsh, S., \& Lakzadeh, L. (2010). Knowledge, attitudes and practices of workers on food hygienic practices in meat processing plants in Fars, Iran. Food control, 21(3), 260-263. https://doi.org/10.1016/j.foodcont.2009.06.003

Eriksen, K., \& Fallan, L. (1996). Tax knowledge and attitudes towards taxation; A report on a quasiexperiment. Journal of economic psychology, 17(3), 387-402. https://doi.org/10.1016/0167-4870(96)00015-3

Ghanizadeh, A., Bahredar, M. J., \& Moeini, S. R. (2006). Knowledge and attitudes towards attention deficit hyperactivity disorder among elementary school teachers. Patient Education and Counseling, 63(1-2), 84-88. https://doi.org/10.1016/j.pec.2005.09.002

Mentari, N. W., Setiawina, I. N. D., Budhi, I. M. K. S., \& Sudirman, I. W. (2019). Influence factor of consumers interest on using E-money. International Journal of Social Sciences and Humanities, 3(2), 176-186.

Notoatmodjo, S. (2010). Ilmu perilaku kesehatan.

Notoatmodjo, S. (2011). Kesehatan masyarakat ilmu dan seni.

Oktaviani, D. (2015). The Effect of Group Guidance Services on Discussion Techniques on Premarital Sexual Behavior of Students at Kerjo Public High School, Karanganyar Regency, Academic Year 2015/2016.

Rahmad, I., Fathoni, A., \& Ahmad, A. (2020). Effect of Syair Biola Katipu Education on Family Concerning Dengue Hemorrhagic Fever Prevention Knowledge. International Journal of Social Sciences and Humanities, 4(1), 5967.

Salman, M. (2012). Evaluating the association between endometrial cancer and polycystic ovary syndrome. Human reproduction, 27(5), 1327-1331.

Sarwono, J. (2013). 12 Jurus Ampuh SPSS Untuk Riset Skripsi. Elex Media Komputindo.

Sekarrini, L. (2012). Faktor-faktor yang berhubungan dengan perilaku seksual remaja di SMK Kesehatan di Kabupaten Bogor tahun 2011. Skripsi. Depok: FKM UI.

Shi, Y., Wang, J., Yang, Y., Wang, Z., Wang, G., Hashimoto, K., ... \& Liu, H. (2020). Knowledge and attitudes of medical staff in Chinese psychiatric hospitals regarding COVID-19. Brain, Behavior, \& Immunity-Health, 4, 100064. https://doi.org/10.1016/j.bbih.2020.100064

Suhron, M. (2016). Asuhan keperawatan konsep diri: Self esteem.

Suhron, M. (2017). Asuhan keperawatan jiwa konsep self esteem. Jakarta: Mitra Wacana Media. 
Suhron, M., \& Amir, F. (2018). Reduce Violent Behavior Schizophrenia: A New Approach Using LT (Laughing Therapy) and DRT (Deep Relaxation Therapy). Indian Journal of Public Health Research \& Development, 9(8).

Suhron, M., \& Zainiyah, Z. (2021). How Were Stress Family and INSR (Insulin Receptor) Expression in Polycystic Ovary Syndrome (PCOS) Insulin Resistant in Madurese Tribe?: Indonesia. Systematic Reviews in Pharmacy, 12(1), 170-175.

Suhron, M., Sulaihah, S., \& Yusuf, A. H. (2017). Model of Potential Strengthening and Family Roles in Improving Family Members for ODGJ Adaptability. In Proceeding of The 2nd International Symposium of Public Health (pp. 344-351). Faculty of Public Health Universitas Airlangga.

Suhron, M., Yusuf, A., \& Subarniati, R. (2019). Assessment of Stress Reactions and Identification of Family Experiences in Primary Care Post Restrain Schizophrenia in East Java Indonesia. Mix Method: Sequential Explanatory. Indian Journal of Public Health Research \& Development, 10(12).

Suhron, M., Yusuf, A., Subarniati, R., Amir, F., \& Zainiyah, Z. (2020). How does forgiveness therapy versus emotion-focused therapy reduce violent behavior schizophrenia post restrain at East Java, Indonesia?. International Journal of Public Health, 9(4), 314-319.

Tana, M. G. (2010). Exploring cortical attentional system by using fMRI during a Continuous Perfomance Test. Computational intelligence and neuroscience, 2010.

Yabancı, N., Kısaç, İ., \& Karakuş, S. Ş. (2014). The effects of mother's nutritional knowledge on attitudes and behaviors of children about nutrition. Procedia-Social and Behavioral Sciences, 116, 4477-4481. https://doi.org/10.1016/j.sbspro.2014.01.970

Yusuf, A., Suhron, M., \& Subarniati, R. (2019). Assessment of the Kempe Family Stress Inventory in self-care postrestrain schizophrenia. International Journal of Public Health Science (IJPHS), 8(2), 55-59.

Yusuf, A., Sulaihah, S., Nihayati, H. E., \& Suhron, M. (2020). The Role Of Families Caring For People With Mental Disorders Through Family Resilience At East Java, Indonesia: Structural Equation Modeling Analysis. Systematic Reviews in Pharmacy, 11(9), 52-59. 